\title{
Development Strategy of Environmentally Friendly Based for Micro, Small and Medium Enterprise
}

\author{
Christianingrum Christianingrum \\ Department of Management, Faculty of Economics \\ Universitas Bangka Belitung \\ Pangkalpinang, Indonesia \\ Christianingrum02@gmail.com
}

\author{
Saputra Putra Pratama \\ Department of Sociology, Faculty of Social and Political \\ Sciences \\ Universitas Bangka Belitung \\ Pangkalpinang, Indonesia \\ Putraps92@gmail.com
}

\begin{abstract}
This study aims to determine an environmentally based business development strategy for Micro, Small, Medium Enterprises. The analysis method used in this study is a SWOT analysis with research samples taken from 33 respondents from the cracker processing industry in Kurau Village. Data collection by observation, questionnaires and secondary data. The SWOT analysis results obtained the IFAS value, which indicates that the Strength $(S)$ is greater than the Weakness (W); this potential strength can be maximized for development efforts in the cracker processing industry in Kurau Village. The EFAS value shows that the opportunity value $(O)$ is greater than the Threat $(T)$ value. The SWOT analysis diagram found that the environmentally-based cracker processing industry in Kurau Village is in quadrant $\mathbf{1}$, which supports an aggressive strategy. Strategies that can be implemented include the company being able to continuously innovate products to produce competitive products, provide training and skills programs carried out by the company to improve human resources better, the existence of production process technology updates to create better product quality, and government support. Government support and businessrelated activities encourage people to choose to trust the company
\end{abstract}

Keywords: Development Strategy, Environmentally Friendly, SWOT Analysis

\section{INTRODUCTION}

SMEs in Indonesia are still the majority business sector compared to large industries. The rapid development of the Small and Medium Enterprises sector in Indonesia is inseparable from SMEs' characteristics, which are business sectors that are resilient to global risks. It is proven that during the Global crisis that occurred some time ago, UKM was present as a solution to a healthy economic system. SMEs are one of the industrial sectors that are slightly or not affected by the global crisis that has hit the world. With this evidence, it is clear that SMEs can be taken into account to increase market competitiveness and stabilize the existing economic system[1], [2].

Even though SMEs have an essential role in driving the national economy, they must continue to innovate continuously in developing their businesses so that the flow of liberalization does not erode them. SMEs must be able to take every opportunity by absorbing the development of consumer expectations for a product. Currently, modern society in choosing a product expects that people prefer environmentally friendly products. This is in line with the growing public awareness of environmental sustainability, which is currently very severely damaged [3],[4]. This shows that MSMEs have a significant contribution to environmental quality degradation caused by waste produced in various forms, inefficient production processes both in the use of raw materials, energy, and the use of other supporting materials

Bangka Belitung Province also has many SMEs that contribute to people's income. Most of the existing SMEs are conventional SMEs, and some lead to environmentally friendly SMEs. To encourage traditional SMEs to be environmentally friendly requires various information from both internal and external sides. From the inner side, aspects that need to be known include the awareness and perception of business actors regarding environmental issues, interests, interests, and readiness of business actors and their businesses or those switching from conventional to environmentally friendly systems. Other important information needed is the various obstacles or difficulties that MSMEs may face in the management, technical, marketing, and financing aspects required by business actors in their efforts to migrate from conventional systems to environmentally friendly procedures. From the external side, the crucial factor that needs to be known is the role of financial institutions and related stakeholders (Ministry of Environment and Government). This research focuses on the strategy of developing environmentally friendly SMEs in the context of the green industry. More specifically, this research needs to be done to determine what methods can be applied to make the processing industry sector in Bangka Belitung, especially the Kurau region, Koba region, become environmentally friendly SMEs.

\section{LITERATURE REVIEW}

\section{Definition of SWOT}

SWOT stands for strengths, weaknesses, opportunities, and threats, where SWOT is used as a model 
for analyzing a profit and non-profit oriented organization to know the state of the organization more comprehensive [5] SWOT analysis is the systematic identification of various factors to formulate a company strategy. This analysis is based on the logic that maximizes strengths and opportunities, but at the same time, minimizes weaknesses and threats [6]. The strategic decision-making process is always related to developing the mission, strategic objectives, and company policies. Thus, the strategic planner must analyze the company's strategic factors (strengths, weaknesses, opportunities, and threats) in the current conditions.

Strengths, Weaknesses, Opportunities, and Threats factors Strengths, Weaknesses, Opportunities, and Threats, among others [7]:

a) Strength factors. What is meant by strength factors possessed by a company, including business units, includes, among other things, the unique competencies contained in the organization, which results in comparative advantage ownership by business units in the market? Because a business has a source of skills, mainstay products, and so on, that make it stronger than competitors in satisfying market needs that are planned to be served by the business unit it is doing.

b) Weakness factors. Namely, limitations or deficiencies in terms of resources, skills, and abilities that are a severe barrier to satisfying organizational performance. In practice, the various rules and shortcomings of these abilities can be seen in the facilities and infrastructure that are owned or not owned, low managerial skills, marketing skills that are not by market demands, products that are less desirable by users or potential users, and the level of income is less. Adequate.

c) Chance factors. A simple definition of opportunity in various favorable environmental situations for a business unit, which is meant by multiple positions, including: 1) Important trends that occur among product users. 2) Identification of a market segment that has not received attention. 3) Changes in competitive conditions. 4) Changes in-laws and regulations that open up new opportunities for business activities. 5) Connect with "close" buyers. 6) Dealing with "harmonious" suppliers.

d) Threat factor. The definition of a threat is the opposite of the understanding of the opportunity. Thus it can be said that risks are environmental factors that do not benefit a business unit. If it is not immediately addressed, the Threat will become a "hurdle" for the business unit concerned both now and in the future.

Based on the [8] concerning Micro, Small and Medium Enterprises, the definition of MSMEs is:

1. Micro Business is a productive business owned by an individual or an individual business entity that meets Micro Business criteria as regulated in this Law.

2. Small Business is a productive economic business that stands alone, which is carried out by individuals or business entities that are not a subsidiary or branch of an owned, controlled, or part, either directly or indirectly, a medium or large business. Criteria for Small Business as referred to in this Law.

3. Medium Business is a productive economic business that stands alone, which is carried out by an individual or a business entity that is not a subsidiary or branch of a company that is owned, controlled, or is part of, either directly or indirectly, with a small or large business with total assets. Net or annual sales proceeds as regulated in this Law.

Furthermore, the criteria for MSMEs based on the [8] are described in the following table:

\section{TABLE 1. UMKM CRITERIA}

\begin{tabular}{|c|c|c|c|}
\hline \multirow[t]{2}{*}{ No. } & \multirow[t]{2}{*}{ Description } & \multicolumn{2}{|c|}{ Criteria } \\
\hline & & Asset & Omzet \\
\hline 1 & $\begin{array}{l}\text { MICRO } \\
\text { BUSINESS }\end{array}$ & 50 Million & $\begin{array}{l}\text { Max. } 300 \\
\text { million }\end{array}$ \\
\hline 2 & $\begin{array}{l}\text { SMALL } \\
\text { BUSINESSES }\end{array}$ & $\begin{array}{l}>50 \text { million - } \\
500 \text { million }>\end{array}$ & $\begin{array}{l}300 \text { million } \\
-2.5 \text { billion }\end{array}$ \\
\hline 3 & $\begin{array}{l}\text { MEDIUM } \\
\text { ENTERPRISES }\end{array}$ & $\begin{array}{l}>500 \text { million } \\
-10 \text { billion> }\end{array}$ & $\begin{array}{l}2.5 \text { billion - } \\
50 \text { billion }\end{array}$ \\
\hline
\end{tabular}

Source: Law of the Republic of Indonesia Number 20 of 2008.

Then in the perspective of its development, SMEs can be classified into 4 (four) groups, namely:

1. Livelihood Activities are SMEs that are used as job opportunities to earn a living, which are more commonly known as the informal sector. An example is a street vendor.

2. Micro Enterprise, which is an SME that is a craftsman but not yet entrepreneurial.

3. Small Dynamic Enterprise is an SME with an entrepreneurial spirit and can accept subcontract and export work.

4. Fast Moving Enterprise is an SME with an entrepreneurial spirit and will transform into a Big Business (UB).

\section{Green Industry}

Green Industry is the commitment of every industry to reduce the impact on the environment due to the production process and the products it produces through continuous efficient use of resources and is low-carbon in nature which is applied to the selection of raw materials, 
production processes, final products, and services in an activity /industry [9], [10].

The green industry is a concept of industrial development that is economically, environmentally, and socially sustainable, where every type of industry can be "green." In the Manila Declaration Action Plan, steps have been formulated to reduce the intensity of natural resource use and carbon emissions from the industrial sector in Asia and monitor efforts on a national scale. In the declaration, the green industry's pillars are the clean production of products and services that are environmentally friendly and growth and competitiveness. Overall, the green industry concept is a way of developing a sustainable industrial sector, both economically, environmentally, and socially [11].

Industries that can apply a green industry are industries engaged in the "environmental good" sector and services, including: industrial recyclers, waste processing, waste destroyers, waste carriers, environmental consultants, wastewater treatment industries, air pollution controllers, processing equipment waste, industrial manufacturing and installation of renewable energy equipment, energy consultants, specialized laboratories for environmental measurement and analysis, and industries producing clean technology. According to the [12], the consumption of natural resources per capita in the Asian region is much lower than that of developed countries. Green Industry is an industry that in the production process prioritizes efficiency and effectiveness in sustainably using resources so that it can harmonize industrial development with the preservation of environmental functions and can provide benefits to society [13].

\section{RESEARCH METHOD}

The research was conducted in the manufacturing sector in Kurau Village, Koba District, and Bangka Belitung Islands Province. The search for data was carried out directly through interviews at the location so that the data obtained for this study was proven to be correct. And the data received will be used in problem-solving in the research process.

The data analysis technique used in this research uses the SWOT analysis technique with a qualitative approach, which consists of Strengths, Weaknesses, Opportunities, and Threats. SWOT analysis aims to maximize strengths and opportunities but can minimize weaknesses and threats.

\section{RESULT}

The questions in this study used the assessment criteria of the green industry. The results obtained in this study can be seen in the following table:

TABLE 2

\section{ANALYSIS SWOT}

\begin{tabular}{|c|l|}
\hline Internal factors & \multicolumn{2}{|c|}{ External factors } \\
\hline $\begin{array}{c}\text { 1. Strengths } \\
\text { a. The achievement of } \\
\text { the company's }\end{array}$ & $\begin{array}{l}\text { a. Weaknesses } \\
\text { program in events that }\end{array}$ \\
\hline
\end{tabular}

production efficiency program

b. Input material is easy to obtain

c. The quality of the input material used is maintained

d. The level of water use efficiency (water index reduction) is good

e. Availability of trained company Human Resources (HR)

f. Adequate use of technology

g. Fulfillment of quality standards for waste and waste gas and dust in the company is fulfilled

h. An adequate work environment to improve employee performance and result in production efficiency

i. Most of the company's products already have certificates

2. Weaknesses

a.The level of the company committed to increasing production efficiency is still low

b. The lack of company efforts to improve energy efficiency

c. There has been no company effort in using renewable energy

d. The company's product rejects are still relatively high

e. The low level of efforts to manage production waste

Table 3 above shows the Strengths, Weaknesses, Opportunities, and Threats of 33 entrepreneurs in the processing industry sector in Kurau Village; when the IFAS calculations were carried out, the following data were obtained:

\section{support \\ improvement}

b. Awards obtained in the industrial sector increase the credibility of the public/consumers in the company

c. Social awareness programs such as charity /donations support the publication of the company in the eyes of the community

d. There is support in the form of training from the government

\section{Threats}

a. There are competitors from both producers and marketers with the same type of product

b. The people's mindset will shift abroad

c. Utilization of waste managed by other parties can reduce the company's credibility in the eyes of the community 
TABLE 3

IFAS CALCULATIONS

\begin{tabular}{|c|c|c|c|}
\hline $\begin{array}{c}\text { Internal Strategy } \\
\text { Factors }\end{array}$ & weight & Rating & Score \\
\hline \multicolumn{4}{|l|}{ Strengths } \\
\hline $\begin{array}{l}\text { The achievement of } \\
\text { the company's } \\
\text { production efficiency } \\
\text { program }\end{array}$ & 0.10 & 5.00 & 0.5 \\
\hline $\begin{array}{l}\text { Input material is easy } \\
\text { to obtain }\end{array}$ & 0.07 & 3.00 & 0.2 \\
\hline $\begin{array}{l}\text { The quality of the } \\
\text { input material used is } \\
\text { maintained }\end{array}$ & 0.10 & 4.00 & 0.4 \\
\hline $\begin{array}{l}\text { The level of water use } \\
\text { efficiency (water index } \\
\text { reduction) is good }\end{array}$ & 0.03 & 3.00 & 0.1 \\
\hline $\begin{array}{l}\text { Availability of trained } \\
\text { company Human } \\
\text { Resources (HR) }\end{array}$ & 0.10 & 4.00 & 0.4 \\
\hline $\begin{array}{l}\text { Adequate use of } \\
\text { technology }\end{array}$ & 0.07 & 3.00 & 0.2 \\
\hline $\begin{array}{l}\text { Fulfillment of quality } \\
\text { standards for waste } \\
\text { and waste gas and dust } \\
\text { in the company is } \\
\text { fulfilled }\end{array}$ & 0.03 & 3.00 & 0.1 \\
\hline $\begin{array}{l}\text { A fair work } \\
\text { environment to } \\
\text { improve employee } \\
\text { performance and result } \\
\text { in production } \\
\text { efficiency }\end{array}$ & 0.07 & 4.50 & 0.3 \\
\hline $\begin{array}{l}\text { Most of the company's } \\
\text { products already have } \\
\text { certificates }\end{array}$ & 0.10 & 5.00 & 0.5 \\
\hline Total Strengths & 0.67 & & 2.7 \\
\hline Weaknesses & weight & Rating & Score \\
\hline $\begin{array}{l}\text { The level of the } \\
\text { company committed to } \\
\text { increasing production } \\
\text { efficiency is still low }\end{array}$ & 0.10 & 1.00 & 0.1 \\
\hline $\begin{array}{l}\text { The lack of company } \\
\text { efforts to improve } \\
\text { energy efficiency }\end{array}$ & 0.03 & 2.50 & 0.083333 \\
\hline $\begin{array}{l}\text { There has been no } \\
\text { company effort in } \\
\text { using renewable } \\
\text { energy }\end{array}$ & 0.07 & 2.00 & 0.133333 \\
\hline $\begin{array}{l}\text { The company's product } \\
\text { rejects are still } \\
\text { relatively high }\end{array}$ & 0.10 & 1.00 & 0.1 \\
\hline $\begin{array}{l}\text { The low level of steps } \\
\text { to manage production } \\
\text { waste }\end{array}$ & 0.03 & 2.00 & 0.066667 \\
\hline
\end{tabular}

\begin{tabular}{|l|l|l|l|}
\hline Total Strengths & $\mathbf{0 . 3 3}$ & & $\mathbf{0 . 4 8 3 3 3 3}$ \\
\hline TOTAL & $\mathbf{1 . 0 0}$ & & $\mathbf{3 . 1 8 3 3 3 3}$ \\
\hline
\end{tabular}

Table 4 above shows that the number of strengths possessed by the cracker processing industry in Kurau is higher than its weaknesses; the next step is to conduct an EFAS analysis to be able to find suitable strategies applied by the processing industry sector in Kurau Village.

TABLE 4

EFAS CALCULATION

\begin{tabular}{|l|l|l|r|}
\hline \multicolumn{1}{|c|}{$\begin{array}{c}\text { External Strategy } \\
\text { Factors }\end{array}$} & weight & Rating & Score \\
\hline \multicolumn{1}{|c|}{ Opportunities } & & & \\
\hline $\begin{array}{l}\text { Company } \\
\text { participation } \\
\text { program in events } \\
\text { that support business } \\
\text { improvement }\end{array}$ & 0.17 & 5.00 & 0.833333 \\
\hline $\begin{array}{l}\text { Awards obtained in } \\
\text { the industrial sector } \\
\text { increase the } \\
\text { credibility of the } \\
\text { public/consumers in } \\
\text { the company }\end{array}$ & 0.17 & 4.00 & 0.666667 \\
\hline $\begin{array}{l}\text { Social care programs } \\
\text { such as } \\
\text { charity/donations } \\
\text { support publicizing } \\
\text { the company in the } \\
\text { eyes of the public }\end{array}$ & 0.11 & 4.00 & 0.444444 \\
\hline $\begin{array}{l}\text { There is support in } \\
\text { the form of training }\end{array}$ & 0.11 & 3.00 & 0.333333 \\
\hline Total Opportunities & 0.56 & & 2.277778 \\
\hline Threats & & & \\
\hline $\begin{array}{l}\text { There are } \\
\text { competitors from } \\
\text { both producers and } \\
\text { marketers with the } \\
\text { same type of product }\end{array}$ & 0.17 & 1.00 & 0.166667 \\
\hline $\begin{array}{l}\text { The people's } \\
\text { mindset will shift }\end{array}$ & 0.17 & 1.50 & \\
\hline $\begin{array}{l}\text { Utilization of waste } \\
\text { managed by other } \\
\text { parties can reduce } \\
\text { the company's } \\
\text { credibility in the } \\
\text { eyes of the } \\
\text { community }\end{array}$ & 0.11 & 2.50 & 0.277778 \\
\hline \multicolumn{1}{|c|}{} & & & \\
\hline & & & \\
\hline
\end{tabular}


Table 4 above shows that the Opportunity value is greater than the Threat. The opportunity value that is owned is 2,278 , and the threat value is only 0.694 , so that the following picture is obtained:

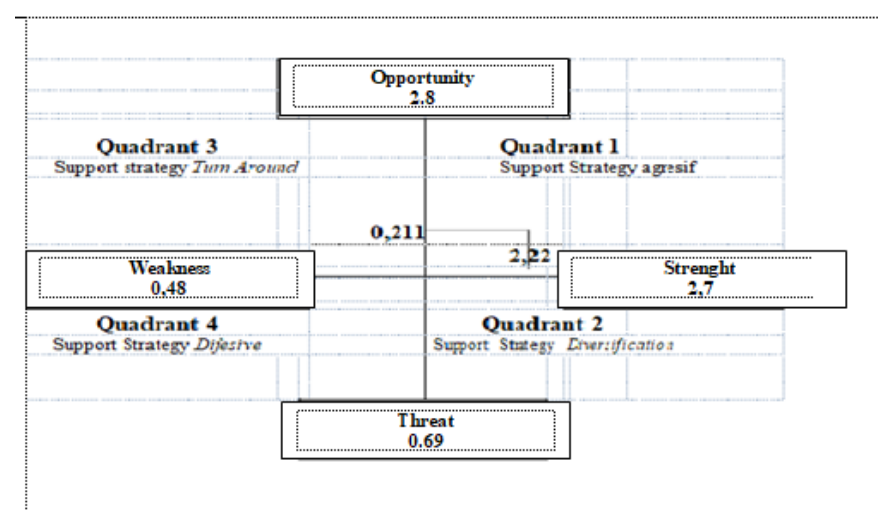

Fig 1

\section{IFAS AND EFAS CALCULATIONS}

After knowing the IFAS and EFAS calculations, a suitable formulation can determine development strategies in the processing industry in Kurau village. The process that can be done include:

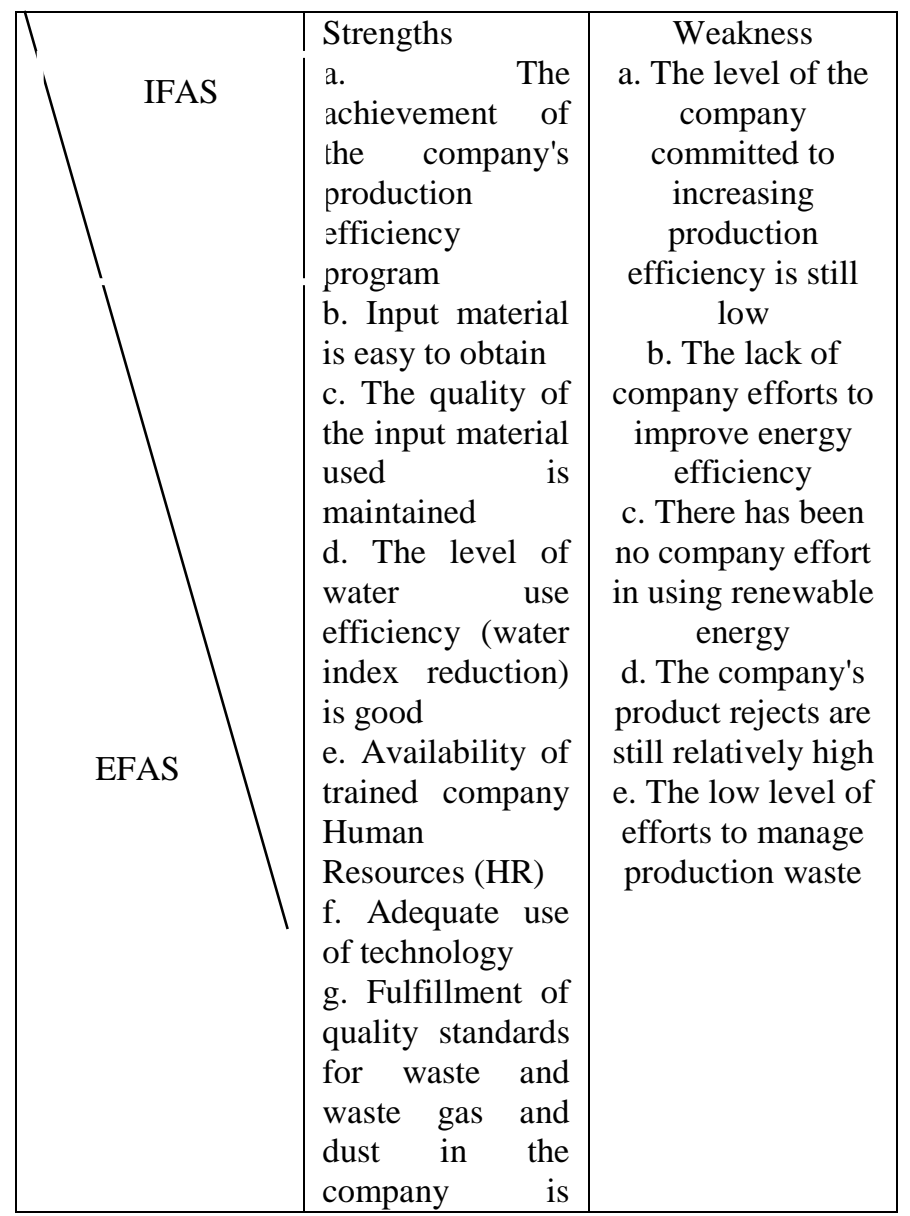

\begin{tabular}{|c|c|c|}
\hline & $\begin{array}{l}\text { fulfilled } \\
\text { h. An adequate } \\
\text { work } \\
\text { environment to } \\
\text { improve } \\
\text { employee } \\
\text { performance and } \\
\text { result in } \\
\text { production } \\
\text { efficiency } \\
\text { i. Most of the } \\
\text { company's } \\
\text { products already } \\
\text { have certificates }\end{array}$ & \\
\hline $\begin{array}{l}\text { Opportunity } \\
\text { a. Company } \\
\text { participation } \\
\text { program in } \\
\text { events that } \\
\text { support business } \\
\text { improvement } \\
\text { b. Awards } \\
\text { obtained in the } \\
\text { industrial sector } \\
\text { increase the } \\
\text { credibility of the } \\
\text { public Social } \\
\text { /consumers in the } \\
\text { company } \\
\text { c. } \\
\text { awareness } \\
\text { programs such as } \\
\text { charity /donations } \\
\text { support the } \\
\text { publication of the } \\
\text { company in the } \\
\text { eyes of the } \\
\text { community } \\
\text { d. There is } \\
\text { support in the } \\
\text { form of training } \\
\text { from government } \\
\text { gone }\end{array}$ & $\begin{array}{l}\text { Strategy (SO) } \\
\text { Supported by the } \\
\text { ease of obtaining } \\
\text { input material, } \\
\text { companies can } \\
\text { continuously } \\
\text { innovate } \\
\text { products to } \\
\text { produce } \\
\text { competitive } \\
\text { products } \\
\text { Continuous } \\
\text { training and } \\
\text { skills programs } \\
\text { are implemented } \\
\text { by the company } \\
\text { to improve } \\
\text { human resources } \\
\text { better to } \\
\text { Renewal of } \\
\text { production } \\
\text { process } \\
\text { technology to } \\
\text { create better } \\
\text { product quality } \\
\text { Support the } \\
\text { government and } \\
\text { business-related } \\
\text { activities } \\
\text { encourage people } \\
\text { to choose to trust } \\
\text { the company }\end{array}$ & $\begin{array}{l}\text { Strategy (WO) } \\
\text { Human resource } \\
\text { empowerment to } \\
\text { increase company } \\
\text { commitment to } \\
\text { production } \\
\text { efficiency } \\
\text { The use of more } \\
\text { advanced } \\
\text { technology to } \\
\text { reduce reject } \\
\text { products }\end{array}$ \\
\hline $\begin{array}{l}\text { Threat } \\
\text { There are } \\
\text { competitors from } \\
\text { both producers } \\
\text { and marketers } \\
\text { with the same } \\
\text { type of product } \\
\text { The people's } \\
\text { mindset will shift } \\
\text { abroad } \\
\text { Utilization of }\end{array}$ & $\begin{array}{l}\text { Strategy }(\mathrm{ST}) \\
\text { Increase } \\
\text { consumer } \\
\text { satisfaction by } \\
\text { improving } \\
\text { product quality } \\
\text { Increasing waste } \\
\text { management } \\
\text { efforts to } \\
\text { increase the } \\
\text { company's }\end{array}$ & $\begin{array}{l}\text { Strategy (WT) } \\
\text { Increase promotion } \\
\text { through print and } \\
\text { electronic media } \\
\text { for the } \\
\text { development of a } \\
\text { more } \\
\text { comprehensive } \\
\text { marketing network }\end{array}$ \\
\hline
\end{tabular}




\begin{tabular}{l|l|l|} 
waste managed & $\begin{array}{l}\text { credibility in the } \\
\text { eyes of the } \\
\text { by other parties } \\
\text { can reduce the } \\
\text { community } \\
\text { credibility in the } \\
\text { eyes of the } \\
\text { community }\end{array}$
\end{tabular}

Fig 2

\section{SWOT ANALYSIS DIAGRAM}

\section{CONCLUSION AND SUGGESTION}

The development strategies that are most suitable to be carried out in the processing industry in Kurau village are: supported by the ease of obtaining input materials, companies can continuously innovate products to produce competitive products, sustainable training, and skills programs implemented by the company to improve human resources better, renewal production process technology to create better product quality, Government support and business-related activities encourage people to choose to trust the company

\section{ACKNOWLEDGMENT}

Our gratitude goes to Bangka Belitung University for providing recommendations to conduct research. We also thank the Directorate of Research and Community Service, Deputy for Strengthening Research, Technology / National Research and Innovation Agency in line with the Research Contract for Fiscal Year 2020 with a Contract Number 142.T/UN50.11/PP/2020.

\section{REFERENCES}

[1] R. Purwaningsih and P. Kusuma Damar, "Analisis faktor- faktor yang mempengaruhi kinerja usaha kecil dan menengah (ukm) dengan metode structural equation modelling (studi kasus UKM berbasis industri kreatif Kota Semarang)," Pros. SNST Fak. Tek. Univ. Wahid Hasyim Semarang, 2015.

[2] Undang-Undang Nomor 20, Tentang Usaha,Mikro,Kecil dan Menengah. 2008

[3] D. Aqmala, "Peluang usaha kecil menengah dalam melakukan inovasi produk ramah lingkungan," Sustain. Compet. Advant., 2013.

[4] S. Williams and A. Schaefer, "Small and Medium-Sized Enterprises and Sustainability: Managers' Values and Engagement with Environmental and Climate Change Issues," Bus. Strateg. Environ., 2013, doi: 10.1002/bse.1740.

[5] S. A. Kadir, R. S. Wardhani, N. Novalia, and A. Maulana, "The Development of Rubber, Coffee and Palm Oil Commodity in South Sumatra, Indonesia using Swot Analysis," Int. J. Environ. Agric. Biotechnol., 2018, doi: 10.22161/ijeab/3.4.6.

[6] E. GÜREL, "SWOT Analysis: A Theoretical Review," J. Int. Soc. Res., 2017, doi: 10.17719/jisr.2017.1832.

[7] B. Phadermrod, R. M. Crowder, and G. B. Wills, "ImportancePerformance Analysis based SWOT analysis," Int. J. Inf. Manage., 2019, doi: 10.1016/j.ijinfomgt.2016.03.009.

[8] Republik Indonesia, Law of the Republic of Indonesia Number 20 Year 2008 Regarding Micro, Small, and Medium Enterprises. Lembaga Negara, 2008.

[9] D. A. Puryono and S. Y. Kurniawan, "Pengukuran Tingkat Efektivitas Kinerja UMKM Batik Bakaran Secara Berkelanjutan Mengunakan Model Green SCOR,” J. Inform. Upgris, 2017, doi: 10.26877/jiu.v3i1.1604

[10] C. Capello, U. Fischer, and K. Hungerbühler, "What is a green solvent? A comprehensive framework for the environmental assessment of solvents," Green Chem., 2007, doi: $10.1039 / \mathrm{b} 617536 \mathrm{~h}$

[11] A. Sartal, R. Bellas, A. M. Mejías, and A. García-Collado, "The sustainable manufacturing concept, evolution and opportunities within Industry 4.0: A literature review," Adv. Mech. Eng., 2020, doi: $10.1177 / 1687814020925232$

[12] OECD, "Enhancing the Contributions of SMEs in a Global and Digitalised Economy," Meet. OECD Counc. Minist. Lev., 2017.

[13] D. Apriyanti, B. Warsito, and T. Prasetyo, "Creating green industry through the implementation of an energy management system: Case study at PT. X," 2018, doi 10.1109/ICPERE.2018.8739493. 